\title{
Hemophagocytic histiocytic sarcoma in feline
}

\author{
Sarcoma histiocítico hemofagocítico em felino
}

\author{
Luciele Varaschini Teixeira ${ }^{\mathrm{I}}$ Danieli Brolo Martins" ${ }^{\mathrm{II}}$ Raqueli Teresinha FrançaII \\ Anne Santos do Amaral ${ }^{\mathrm{II}}$ Cínthia Melazzo Mazzanti" ${ }^{\mathrm{II}}$ Sonia Terezinha dos Anjos Lopes ${ }^{\mathrm{II}}$
}

\section{-NOTE -}

\section{ABSTRACT}

Cytological analysis of the pleural cavity becomes extremely important for the diagnosis of tumors that have no visible or palpable mass. The aim of this study is to report a case of hemophagocytic histiocytic sarcoma in a cat, a rare neoplasm, emphasizing the importance of laboratory tests, especially the analysis of effusions. This report discloses the usefulness of cytology in effusions directing the clinical veterinarian for the correct diagnosis and subsequent treatment.

Key words: neoplasms, cat, diagnosis, effusion analysis.

\section{RESUMO}

A análise citológica das efusões cavitárias tornase de suma importância para o diagnóstico de neoplasmas que não possuem massa visível ou palpável. O objetivo deste trabalho é relatar um caso de sarcoma histiocítico hemofagocítico em um felino, um neoplasma de ocorrência rara, enfatizando a importância dos exames laboratoriais, ${ }^{1}$ principalmente análise de efusões. Este relato expõe a utilidade da análise citológica das efusões direcionando o clínico veterinário para o diagnóstico correto e posterior tratamento.

Palavras-chave: neoplasma, gato, diagnóstico, análise de efusões.

Histiocytic sarcoma is characterized by the malignant proliferation of dermal tissue histiocytes (local) or in other organs (disseminated) (AFFOLTER
\& MOORE, 2006). It was formerly interpreted as a true histiocytic lymphoma, affecting animals in advanced age (SCOTT et al., 2001).

The histiocytic sarcoma of the hemophagocytic type initially involves the spleen and bone marrow, affecting liver and lungs later, with minimal lump formation and outstanding hemophagocytosis. Such neoplasia is rare, of unknown etiology and quick development, with formation of metastases to other organs and tissues (MOORE et al., 2006; PINARD et al., 2006).

In many cases, intra-thoracic and intraabdominal neoplasms are diagnosticated through cytological analysis in body cavity fluids, mostly when there is a significant tumor cell exfoliation. So, neoplastic effusions are classified as modified transudate or exudate, according to increasing cellularity and the presence of protein (RIZZI et al., 2008).

The present research aims to describe a hemophagocytic histiocytic sarcoma in a feline, with emphasis on the importance of laboratory examinations, especially effusion analyses, when there is no visible or touchable neoplasm. Moreover, this report shows the utility of cytological analysis in effusions, conducting the veterinarian to a correct diagnosis and consequent treatment.

'Laboratório de Análises Clínicas Veterinárias da Universidade Federal do Rio Grande do Sul (LacVet - UFRGS), 91540-000, Porto Alegre, RS, Brasil. E-mail: luciele.sm@gmail.com. Autor para correspondência.

"Laboratório de Análises Clínicas Veterinárias da Universidade Federal de Santa Maria (LacVet - UFSM), UFSM, Santa Maria, RS, Brasil.

IIIDepartamento de Clínica de Pequenos Animais, Hospital Veterinário Universitário (HVU), UFSM, Santa Maria, RS, Brasil. 
In the Veterinary University Hospital of the Universidade Federal de Santa Maria (VUH - UFSM) a female feline, nine years old with no specified race, has been treated for presenting respiratory failure and great dehydration. By the time of the clinical examination it showed a very bad nutritional status, pale mucous membranes and hair standing on end. Chest radiography demonstrated an increase of mediastinal volume, from where $250 \mathrm{~mL}$ of yellow liquid has been later drained. A percentage of such liquid has been sent to the Laboratory of Veterinary Medical Analyses (LVMA - UFSM) together with blood samples for making a complete blood count and serum biochemistry.

Hematological data demonstrated to be within normal parameters for that feline species. However, serum biochemistry presented alterations. The value for serum alanine aminotransferase (ALT) and gamma glutamiltransferase (GGT) were above normal $\left(181,28 \mathrm{UI} \mathrm{L}^{-1}\right.$ and $\left.6,93 \mathrm{UI} \mathrm{L}^{-1}\right)$, meanwhile albumin presented a low value $\left(1,83 \mathrm{~g} \mathrm{dL}^{-1}\right)$, considering the normal values for that species: ALT $\left(28-83 \mathrm{UI} \mathrm{L}^{-1}\right)$, GGT (1,3-5,1UI L $\left.\mathrm{L}^{-1}\right)$ and albumin: $\left(2,1-3,3 \mathrm{~g} \mathrm{dL}^{-1}\right)$.

Analysis in the thoracic liquid is in according to Martins et al. (2011), and resulted in: nuclear cells $4200 \mu \mathrm{L}^{-1}$, density $1,036, \mathrm{pH} 7,0$ and protein $6,0 \mathrm{~g} \mathrm{dL}^{-1}$. Also a large amount of nuclear cells, round with clear nucleolus, showing erythro- and leukophagocytosis, as well as abnormal mitoses. Findings have been strongly suggestive of malignant neoplasia from round cells. Among such cells, the presence of small lymphocytes, neutrophils, erythrocytes and macrophages was observable in less percentage.

Based on such data, the veterinarian decided for the therapy with prednisone, cyclophosphamide and vincristine. Two months after the beginning of the treatment the feline presented once more serious dehydration and anorexia, so an euthanasia was performed by decision of the owner of the animal. The animal has soon been taken to the Department of Veterinary Pathology (DVP) for necropsy. So, neoplasm in the mediastinal cavity and multifocal metastases in the spleen and in the liver have been recorded, later confirmed in the histopathology as being a hemophagocytic histiocytic sarcoma.

The hemophagocytic histiocytic sarcoma is characterized by the visceral implication, usually affecting the spleen, liver, lymph nodes and lungs (FULMER \& MAULDIN, 2007). About this patient, the initial tumor affected the mediastinal cavity. The erythrophagocytosis by the neoplastic histiocytes becomes an ultimate characteristic for diagnosis, showing also a relationship between cases in which anemia and other cytopenias use to happen (JACOBS et al., 2002).

In this case, erythrogram has not presented any anemia, considering that dehydration concentrates the blood components (WATSON, 2000). Leukometry stayed within standard deviation, excepting lymphocyte count $\left(524 \mu \mathrm{L}^{-1}\right)$, which presented values below normality for that species $\left(1500-7000 \mu \mathrm{L}^{-1}\right)$. Lymphopenia is quite common in animals with neoplasia, and it is usually followed by normochromic normocytic anemia. In cats it is usually assigned to endogenous corticosteroids effects, liberated during periods of stress caused by neoplasia. Besides, some neoplasm types send lymphocytes to the growing point, just like in the case of the tumor type reported here (KERR, 2002; RIZZI et al., 2008). Many studies have been demonstrating the presence of anemia in histiocytic tumors, as much concerning to phagocytosis by neoplastic cells, as by hypoplasia and bone marrow infiltration of neoplastic histiocytes (FRIEDRICHS \& YOUNG, 2008).

In this case, the ALT, a seeping out enzyme, demonstrated a high level because of the multifocal injuries in the hepatocytes caused by histiocytic sarcoma metastases. In multifocal injuries like hepatic neoplasia, the activity of enzymes for induction, as the GGT, may demonstrate a normal standard. Meanwhile there is a possibility of increasing, in case of significant cholestasis caused by focal injuries (LASSEN, 2007). The low concentration of plasmatic proteins, mostly hypoalbuminemia, may have hepatic and extrahepatic causes (KERR, 2002). In this study, the main causes for serum albumin decrease was related to the absence of ingestion and the insufficient production by the patient's liver, considering that the organ's function was already damaged by metastasis.

The evaluation of the thoracic effusions becomes an even more important device when it concerns to neoplasia, for beyond obtaining the classification of the drained liquid, cytology contributes to make an ultimate diagnosis of the disease. Cellularity is the most important component in the effusions, for it shows the source of the body cavity liquid (HIRSCHBERGER \& SAUER, 1991).

Cytologic diagnosis of the effusions is a highly specified method in supporting the veterinarian to make the prognostic for the animal (DI BONITO et al., 1993). Nevertheless, there is still resistance to the sensibility concerning to liquid-based cytology, often achieving suspicious results (WOJNO et al., 1994). 
The cytology of cavity apoplexies plays an important role in metastasis detection, moreover delineating the difference between benign and malignant injuries, as well as non-neoplastic injuries. Meanwhile, the discrimination between the several cell types present in body cavity liquids may be compromised by false-positive or false-negative test results (LONGATTO FILHO et al., 1998).

HIRSCHBERGER et al. (1999) achieved 67\% and $75 \%$ sensibility in cytologic evaluation of pleural and peritoneal effusions, respectively, and $100 \%$ specificity in both effusions. However, ELSE \& SIMPSON (1988) obtained 100\% in their studies concerning to specificity, as well as sensibility, in cytologic diagnosis of neoplasm effusions in cavities of dogs and cats. In this case, a low sensibility and a high specificity relative to the examined pleural liquid are remarkable, for there was pleomorphism in the studied neoplastic cells.

The histiocytic sarcoma is composed by round cells, set individually or in little amounts. It contains merely granulated and basophilic cytoplasm, with small vacuoles, anisocytosis and anisocariosis. Nuclear chromatin is thick and contains a proeminent nucleole. Phagocytosis and multinucleation are often reported. Other cell types include small lymphocytes, macrophages and neutrophils (PINARD et al., 2006). In this case, neoplastic histiocytic cells contained leukocytes and erythrocytes inside. It is important to emphasize that such cells are easily mistaken for other round cell types, such as neoplastic lymphocytes, which can also provoke the formation of thoracic liquid. Therefore, the chemotherapy protocol should be adequate, according to the findings taken from clinical laboratory findings.

In conclusion, hemophagocytic histiocytic sarcoma is an effusive neoplasm with poor diagnosis. On such terms, this report demonstrates the importance of making complementary examinations, especially laboratorial ones, in animals with primary effusions as in this case. The cytologic analysis in effusions is extremely useful, for it assists in distinguishing inflammatory from neoplastic effusions, making possible an earlier treatment in this aspect, improving the patient's life quality.

\section{BIOETHICS AND BIOSSECURITY COMMITTEE APPROVAL}

The authors are aware of this report. Furthermore, there is a document signed by the patient's owner which is filed at Veterinary Hospital, which allows the procedures performed.

\section{REFERENCES}

AFFOLTER, V.K.; MOORE, P.F. Feline progressive histiocytosis. Veterinary Pathology, v.43, p.646-655, 2006. Available from: < http://vet.sagepub.com/content/43/5/ 646.short>. Accessed: May., 25, 2010. doi: 10.1354/vp.43-5646 .

DI BONITO, L. et al. The positive peritoneal effusion: a retrospective study of cytopathologic diagnoses with autopsy confirmation. Acta Cytologica, v.37, p.483-488, 1993.

ELSE, R.W.; SIMPSON, J.W. Diagnostic value of exfoliative cytology of body fluids in dogs and cats. Veterinary Record, v.123, p.70-76, 1988. Available from: <http:// veterinaryrecord.bmj.com/content/123/3/70.abstract $>$. Accessed: Feb., 28 2010. doi: 10.1136/vr.123.3.70.

FRIEDRICHS, K.R.; YOUNG, K.M. Histiocytic sarcoma of macrophage origin in a cat: case report with a literature review of feline histiocytic malignancies and comparison with canine hemophagocytic histiocytic sarcoma. Veterinary Clinical Pathology, v.37, p.121-128, 2008. Available from: <http:// onlinelibrary.wiley.com/doi/10.1111/j.1939165X.2008.00005.x/full>. Accessed: Jan., 21, 2010. doi: 10.1111/j.1939-165X.2008.00005.x.

FULMER, A.K.; MAULDIN, G.E. Canine histiocytic neoplasia: an overview. Canadian Veterinary Journal, v.48, p.10411050, 2007. Available from: <http://www.ncbi.nlm.nih.gov/ pmc/articles/PMC1978291/>. Accessed: Set., 24, 2009. doi: 1978291.

HIRSCHBERGER, J. et al. Sensitivity and specificity of cytologic evaluation in the diagnosis of neoplasia in body fluids from dogs and cats. Veterinary Clinical Pathology, v.28, p.142-146, 1999. Available from: <http:// onlinelibrary.wiley.com/doi/10.1111/j.1939165X.1999.tb01065.x/pdf>. Accessed: Abr., 2, 2009. doi: 10.1111/j.1939-165X.1999.tb01065.x.

HIRSCHBERGER, J.; SAUER, U.G. Klinisch-chemische Untersuchung von Korperhohlenergussen. Tierantl Praxis, v.19, p.431-434, 1991. Available from: <http:// onlinelibrary.wiley.com/doi/10.1111/j.1939165X.1999.tb01065.x/pdf>. Accessed: May., 29, 2008. doi: 10.1111/j.1939-165X.1999.tb01065.x.

JACOBS, R.M. et al. Tumors of the hemolymphatic system. In: MEUTEN, D.J. Tumors in domestic animals. Iowa: State, 2002. Cap.3, p.119-198.

KERR, M.G. The white blood cells (leucocytes). In: Veterinary laboratory medicine - Clinical biochemistry and haematology. 2.ed. Oxford: Blackwel Science, 2002. Cap.3, p.135-148.

LASSEN, E.D. Avaliação laboratorial do fígado. In: THRALL, M.A. Hematologia e bioquímica clínica veterinária. São Paulo: Roca, 2007. Cap.23, p.335-354.

LONGATTO FILHO, A. et al. Sensibilidade do método citológico para o estudo de derrames cavitários: correlação com o tipo histológico das neoplasias. A Folha Médica, v.116, p.91-94, 1998. 
MARTINS, D.B. et al. Thoracic and abdominal mesothelioma in a dog: a cytologist's view. Comparative Clinical Pathology, v.20, p.289-293, 2011. Available from: <http:// www.ingentaconnect.com/content/klu/580/2011/00000020/ 00000003/00001177>. Accessed: Out., 05, 2011. doi: 10.1007/ s00580-011-1177-8.

MOORE, P.F. et al. Canine hemophagocytic histiocytic sarcoma: A proliferative disorder of CD11d+ macrophages. Veterinary Pathology, v.43, p.632-645, 2006. Available from: $<$ http://vet.sagepub.com/content/43/5/632.full.pdf $>$. Accessed: Set., 15, 2009. doi: 10.1354/vp.43-5-632.

PINARD, J. et al. Histiocytic sarcoma in the tarsus of a cat. Veterinary Pathology, v.43, p.1014-1017, 2006. Available from: < http://vet.sagepub.com/content/43/6/1014.full $>$. Accessed: Mar., 14, 2009. doi: 10.1354/vp.43-6-1014.
RIZZI, T.E. et al. Efusões abdominal, torácica e pericárdica. In: ___ et al. Diagnóstico citológico e hematologia de cães e gatos. 3.ed. Missouri: Mosby Elsevier, 2008. Cap.15, p. $235-254$.

SCOTT, D.W. et al. Neoplastic and non-neoplastic tumors. In: _. Muller \& Kirk's - Small animal dermatology. 6.ed. Philadelphia: Saunders, 2001. p.1528.

WATSON, A.D.J. Erythrocytosis and polycythemia. In: FELDMAN, B.V. et al. Schalm's veterinary hematology. Baltimore: Lippincott Williams e Wilkins, 2000. p.216-221.

WOJNO, K.J. et al. Cytopathology of pleural effusions after radiotherapy. Acta Cytologica, v.38, p.1-8, 1994. 